\title{
Project Based Learning on SD 2 Practicum Education Eyes to Improve the Creativity of Media Making Innovative
}

\author{
Nur Ngazizah, Arum Ratnaningsih, Titi Anjarini, Rintis Rizkia Pangestika \\ \{ngazizah@umpwr.ac.id ${ }^{1}$ \}
}

PGSD Study Program, Muhammadiyah University of Purworejo, Purworejo, Indonesia ${ }^{1,2,3,4}$

\begin{abstract}
This study aims to improve creativity in making innovative science tools for science learning in elementary schools using project-based learning materials. The object of this research is the fourth semester students of the PGSD study program at the FKIP Muhammadiyah University of Purworejo in the even semester of academic year 20172018 which consists of classes A and B with a total of 30 people. The results showed that the props produced were diverse and useful, even though they used used materials that were previously less valuable. From the $100 \%$ report value data, each group achieved values above 80 , while for teaching aids products $65.6 \%$ got a score above $80,25.3 \%$ got a score of 80 and $9.1 \%$ got a score below 80 . This method learning that is used to improve and train students in groups to make tools with results and also from existing tools.
\end{abstract}

Keywords: project-based development, science teaching aids, innovative, creativity, used materials

\section{Introduction}

Science and technology that are developing at this time require the professionalism of teachers in educating their students. Teacher professionalism cannot replace its role in the formation of students' insight, skills and intellectual maturity, because it is an important task of education. The taxonomy of media objectives is a basis for formulating learning objectives. Taxonomy is the goal of cognitive, affective, and psychomotor domains. So that the teacher as a teacher must be able to break down the condition of students into individuals with prime personality who are able to develop knowledge, skills, values and attitudes. This is important as a foundation to equip them to achieve what they aspire to in the future.

Tik Wang Liem, a science teacher, must have some teaching features, high confidence, creativity, responsibility, a good sense of humor and communication skills. In addition, learning science also requires something that can attract students' interests by using media and teaching aids. This is so that the process is more effective and efficient. Thus a science teacher too must have the ability in making props.

SD 2 Practicum of Science is one of the subjects in PGSD FKIP Muhammadiyah University Purworejo, providing supplies for students to have knowledge about practicum methods and making science media that helps in the learning process in Primary Schools. This course is a compulsory subject of a study program that contains material on the basic foundation of science as a basis for developing creativity and equipping students with skills 
and creating practicum tools and equipment or using existing tools by using resources among which are useful as a tool in the learning process teach.

In this course, making teaching aids hopes to use cheap materials and can use used materials so the costs incurred are not too expensive. Because the results of this lecture are expected to be used for teaching aids or the use of existing tools by using the creativity of each individual, no one is fixated on existing teaching aids.

Props according to experts [1], namely according to Gagne are components that can be used for learning. According to Briggs, props are physical vehicles that contain material. According to Schramm and tools for education in engineering to send messages. According to Miarso, the macro tool is deep interactive learning system as a learning process. Can get comparison use into improve contruction with more and more effects. Because the teaching aids themselves are used to clarify, the students understand the concepts / principles or theories, and make the message more interesting, it is easy for students to improve.

The use of science teaching aids is needed in science learning, so that science learning becomes more real for students. In addition, there are many functions that can be used for communication between learners and teachers, thoughts, feelings, attention and willingness of students in learning, encouragement and interest of students, building a foundation for learning and developing. real experience that can foster participants' independence student.

According to Joel L [2] explains that project-based learning is a learning strategy that empowers students to know new knowledge and understanding based on experience through various presentations. The learning program used is students flow important ideas and ask questions, students find understanding in the process, according to their needs and interests, produce products and think creatively, critically and skillfully, conclude material, and connect with real-world, personal and issues.

Project-based learning is a learning model that provides opportunities for teachers to manage learning in the classroom by involving project work. Working to compile complex tasks based on problems (problems) as a first step in collecting and sharing new knowledge based on experience in real activities and demanding students to do activities, solve problems, make decisions, conduct investigative activities, and provide opportunity for students to work independently or in groups. The final results of the projects are other products from reports or verbally, presentations or recommendations [2].

Based on previous research [3] Words that are developing in the Unnes Science Education study program can develop science teaching aids using used materials. This made me interested in doing research on the student study program of PGSD FKIP Muhammadiyah University of Purworejo in developing innovative science teaching aids that can be used in elementary schools.

\section{Method}

This research is a research for a class designed to improve quality and good cooperation in developing innovative science teaching aids.

There are several stages in learning: (1) choosing one science material in elementary school that needs to be made a tool in the learning process; (2) the design of innovative science teaching aids from used goods and then presented to the class to test their feasibility in terms of practical, pedagogical and cost; (3) revising the influence of props design; (4) making innovative science teaching aids with the provision that the fee is not more than Rp. 25,000; 
(5) presenting the results of teaching aids in class; (6) revising the hell props is more perfect, and (7) making the end of the story about the science teaching aids made.

Collecting data in this study by using (a) Average props products that are presented in class, (b) Final report value of teaching aids. The data obtained is then analyzed with a range between 70-100.

\section{Results and Discussion}

Therefore, it will be very easy if it is used to make media or tools that are more appropriate and suitable for use in the environment using used materials, and other materials that have more value. And the output of this lecture can be directly felt by students using the product.

The target of this class action research is the fourth semester student of PGSD study program for the even semester of 2017/2018 academic year which consists of 2 classes namely class A and B which fight 30 people each. The implementation of learning based on this project is divided in 6 groups and 1 group consisting of 4 people. Result data from props that can be seen in the table 1 .

In this process, some of the tools used to retrieve results from the internet are not the result of the group's own design. For example for human respiratory system props. This happens, maybe students experience difficulties in finding ideas to make or watch existing teaching aids.

The teaching aids that have been presented in front of the class are based on several criteria, namely the attractiveness of the props, the suitability of the chosen material, the appearance of the props, the originality and practicality in the use of props. Because the teaching aids produced later will be in elementary school, the challenge is as attractive as possible for students. Then in addition, the final report also issued from the start of the concept of material; feasibility in terms of practical, pedagogical and cost; making orders; how expensive props work.

Based on Table 1, it can be seen that the value of the report is good, that is $100 \%$ scored above 80 , both class $\mathrm{A}$ and $\mathrm{B}$ with the lowest score 80 and highest 87 . Whereas for the price of props $63.6 \%$ received scores above $80,27,3 \%$ scored 80 and $9.1 \%$ scored below 80 . This shows that students have been able and made innovative science tools and are the results of their own searches.

Researchers also saw that with research conducted in each group, this was proven by more innovative tool products. Thus training using the project can be used as an effective method to improve students' ability to solve problems. Because students will better understand the concept of the facts they are learning from they receive information passively [4]. Projectbased learning (PEL) will also increase participants' responsibilities to solve problems and efforts to become independent learners. Things that will be very useful for those who will come and for their careers later [4].

The aim of science learning in elementary schools based on the 2006 KTSP is (1) to instill knowledge and concepts that are useful in everyday life; (2) instilling curiosity and positive attitudes towards science and technology; (3) develop processes to regulate nature, solve problems, and make decisions; (4) participate in maintaining, maintaining, and preserving natural environment; (5) developing awareness about the interplay between science, 
environment, technology and society; and (6) respecting nature and its order as one of the creations of God Almighty (Depdiknas, 2006).

In line with the goal science learning in elementary school, how knowledge about and make tools that are very important for prospective elementary school teachers. Because elementary school teachers must be able to explain the concepts of science that allow for clearer and easier to understand with the use of teaching aids. In order not to occur misconceptions on students about the concepts of science that will continue to stick in their brains.

The brain of a six- or seven-year-old child's role is like a sponge, hiding facts, physical traits, and the complexity of chaotic language in a fun and stress-free way. The important task of science teachers in helping students develop scientists who can be found in science learning for children who use authentic that involves objects, play, science terms and understanding (Edihendri, 2014).

Designing props or simple experiment tools is necessary the concepts used are the use or working principles, which is to increase understanding of concepts that are not distorted. There are three meanings of feasibility in making good teaching aids, namely (1) practical feasibility: Introduction and introduction of teachers to types of tools, teaching aids in the local learning environment, and time to prepare it, flexibility that is easy to carry and also by anyone; (2) technical / pedagogical feasibility: relevant to the objectives of optimal learning; and (3) cost feasibility, this important by paying attention to the costs incurred with the benefits obtained [1].

Table 1. Name of Props and Report Value

\begin{tabular}{|c|c|c|c|}
\hline Groups A & Props Product & Viewer & report \\
\hline 1 & Water rocket & 81 & 85 \\
\hline 2 & Water filter & 83 & 83 \\
\hline 3 & Simple plane & 86 & 82 \\
\hline 4 & hidraulic & 84 & 80 \\
\hline 5 & Alternative energy & 85 & 80 \\
\hline 6 & Electricity from fruit & 80 & 83 \\
\hline \multicolumn{4}{|l|}{ Groups B } \\
\hline 1 & Water rocket & 87 & 87 \\
\hline 2 & Water filter & 83 & 86 \\
\hline 3 & Simple plane & 85 & 82 \\
\hline 4 & hidraulic & 86 & 81 \\
\hline 5 & Alternative energy & 78 & 83 \\
\hline 6 & Electricity from fruit & 80 & 85 \\
\hline
\end{tabular}

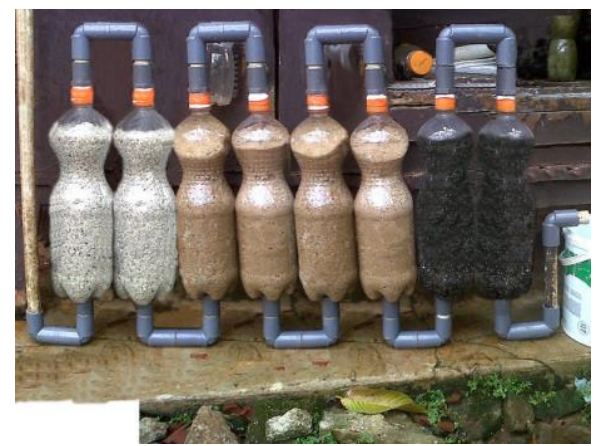

Fig 1. Water filter 


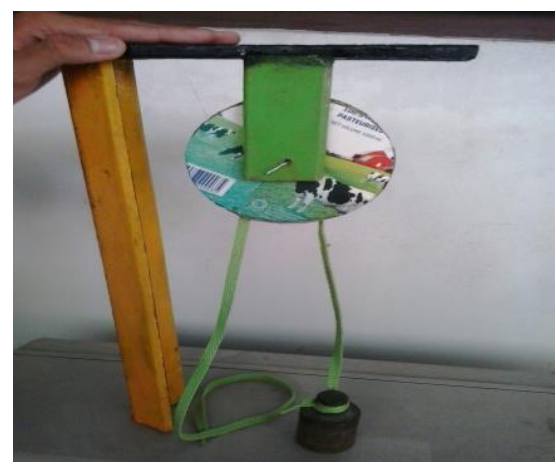

Fig. 2. Simple plane

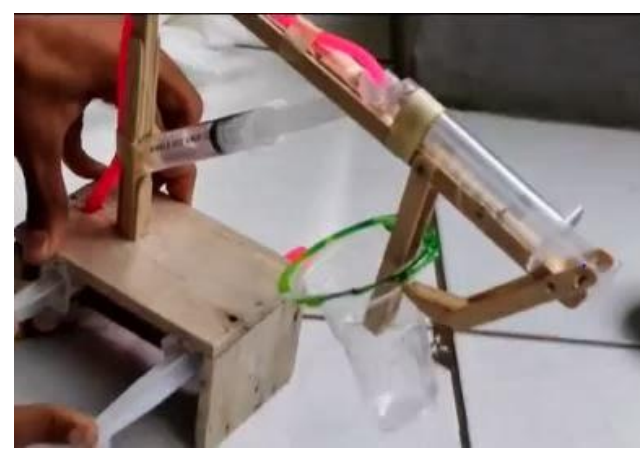

Fig. 3. Hidraulic

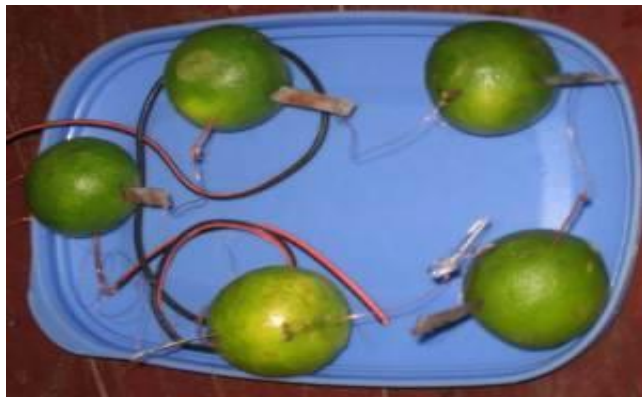

Fig. 4. Electricity from fruit

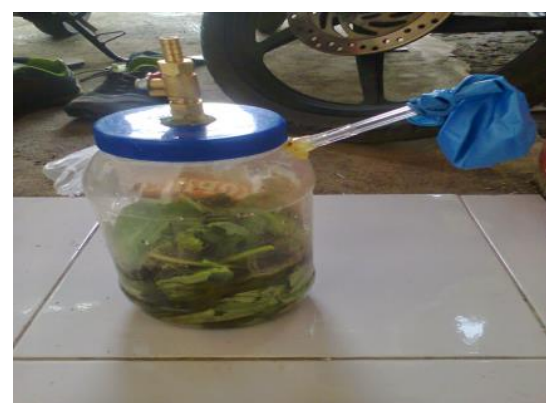

Fig. 5. Alternative energy 


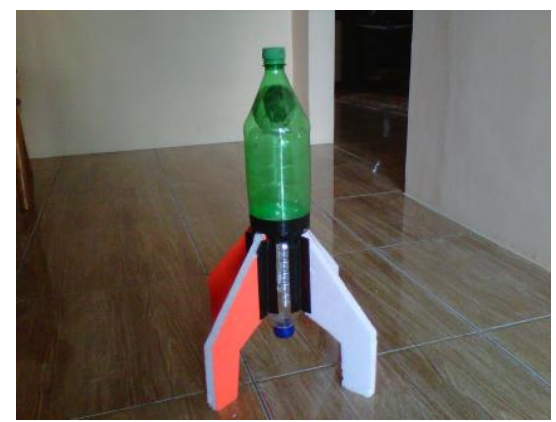

Fig. 6. Water rocket

\section{References}

[1] A. Sapriati, Learning Science at5. Jakarta: Open University, 2009.

[2] T. Widiyantini, "Application of Project Eased Learning Model in Eilangan Pattern Material Class VII," PPPPTK Mathematics. 2014

[3] et al Widiyatmoko, A., "Project Learning to develop science teaching aids using used materials," JPII 1, vol. 1, pp. 51-56, 2012.

[4] H. Putih, "Problem Eased Learning," Stanford University Bulletin on Teaching. 2001. 